\title{
Analysis on Old-Age Security Problem of Landless Peasants and Its Countermeasures on the Process of Urbanization
}

\author{
Meige Liu $^{1, \text { a }}$ \\ ${ }^{1}$ Shaanxi Institute of International Trade \& Commerce, Xianyang, Shaanxi, 712000 \\ ${ }^{\mathrm{a}}$ email
}

\begin{abstract}
Keywords: The Process of Urbanization, Landless Peasants, Pension, Problems, Countermeasures
\end{abstract}

\begin{abstract}
The process of rapid social and economic development, Chinese urbanization and industrialization is also developing rapidly which requires a lot of land as a support, whereby farmers will lose their land and become society obtained a special group, they are called landless farmers. Land has always been an important foundation and safeguard farmers to settle down, but lost land farmers will lose their important source of income, which results in a more severe impact on the lives of farmers. Currently the number of landless peasants in the country increase rapidly and the landless farmers are now against this situation, we need to effectively address the problem of old-age security for farmers. From the point of landless peasant old-age security in the process of urbanization in China, this paper studies these problems and put forward some solutions.
\end{abstract}

\section{Introduction}

Landless peasants old-age security, mainly by the state and the rural collective organizations and individual farmers in accordance with a certain percentage of joint commitment that could ensure that landless farmers after entering old age, still able to maintain their normal life. New type of rural social endowment insurance system now has been able to implement the landless peasants old-age security for effective support. But gradually accelerated from the urbanization process speed, the actual operation itself landless peasants pension insurance system point of view, there are still some problems, need to be actively addressed.

\section{Old-Age Security Problems on the Process of Urbanization}

Accelerating the process of urbanization, urban construction, industrial production and a variety of social needs of the industry, taking up a lot of farmers' land, in order to ensure the normal life of farmers lost their land, it needs to adopt appropriate security system for old-age security important safeguards landless farmers to provide a good life support, the safeguards occupy a very important position in the current development of society, and actively play a good role. But from the specific implementation of the landless peasants old-age security measures point of view, there are still some problems need to be comprehensive and effective analysis and research, to be able to provide a good prerequisite for the subsequent fully resolved.

After the farmers' land is expropriated, compensation method is used in most areas are disposable monetary compensation, but because of land requisition compensation standards in many areas is low, which is the market value of the land will be departing. Peasant survival is an important foundation and prerequisite for the land, when farmers lost their land, the original source of the most basic will be missing, while the lower cost of land acquisition compensation for landless peasant pension insurance and employment situation did not develop full consideration. Especially when fully developed market economy for monetary inflation problem is not considered, the price increase will lead to the problem of land acquisition compensation received by farmers are not able to effectively meet the needs of their own life, serious damage to the vital interests of landless peasants . After accepting the farmers land compensation, we can only deal with the immediate life, and for the future long-term livelihoods and development, and there is no comprehensive outlook. Meanwhile, China's urbanization process for the resettlement compensation method used is 
relatively simple, farmers do not have a good source of income, will cause some adverse effects on the life and development of late, relying solely on a one-off compensation payments, can not effectively solve the landless farmers' pension issues.

Our pension problem for landless peasants to give enough attention to adopt the necessary measures to landless peasant pension lives is protected. Now most parts of the country have introduced the corresponding landless peasants old-age insurance, but due to higher insurance threshold required to pay the higher cost of landless peasants, landless farmers which gives a certain amount of pressure. Current practice in most parts of the government are mostly financial and personal pension contributions shared principles, the burden of which the government usually $60 \%$ of individuals required to pay $20 \%$, but from a practical point of view the situation of landless peasants, they have lost an important economic source, and there is no better employment opportunities in the burden on the pension when the minimum proportion of $20 \%$ is also required to pay pension insurance, face higher pension contribution amount, landless farmers do not have enough confidence and ability to participate among the old-age insurance, which for landless peasants endowment itself adds a certain degree of difficulty [1]. At the time of the 4500 landless peasants living in one town to investigate the situation, living conditions for the evaluation of the loss of their land after the data are as follows.

Table 1 landless peasants living on the existing evaluation Fact Sheet

\begin{tabular}{|c|c|c|}
\hline \multicolumn{2}{|c|}{ Landless peasants living on the existing evaluation Fact Sheet } \\
\hline Evaluation indexes & The numberof households & Proportion \\
\hline Improved obviously & 200 & 0.044 \\
\hline Improved & 900 & 0.200 \\
\hline Unchanged & 1200 & 0.270 \\
\hline Decreased & 2000 & 0.440 \\
\hline Unclear & 200 & 0.044 \\
\hline
\end{tabular}

For landless peasants pension insurance payment, payment method commonly used is not flexible enough, landless peasants in some areas requires a one-time payment of pension costs for a long time, which adds to the landless peasants greater difficulty, landless peasants from their own needs the resulting land compensation spent a large part of old-age insurance premiums. The amount of land compensation to landless peasants itself was not high, so that more need to assume a greater pressure, the farmer can not guarantee normal life [2].

To provide old-age security of landless peasants, they usually are the level of pension benefits and the minimum living standard of the local were flat, so that the level of pension benefits insurance in the current development of society is still relatively low. Landless peasants without land after important support, relying solely on the land compensation sustain daily life, but also took a large part of the money to participate in old-age life Insurance, and that this increases the landless peasants living in the invisible stress [3].

\section{The Method for Landless Peasants Old-Age Security Measures under the Process of Urbanization}

The current level of old-age security benefits for landless peasants is still generally low, and with a certain lag. The level of pension benefits, and does not vary according to the market to enhance economic development, urban workers wages gradually increase, which will lead to landless farmers can not meet their normal lives. Landless peasants against the current pension system is not perfect and sound, mainly in the landless farmers to participate in pension insurance enthusiasm is not high, which is due to pension insurance part of the insured does not have necessarily mandatory, and forced regional participation in pension insurance, landless farmers need to pay a lot of one-time pension costs, which gives landless peasants bring greater pressure [4]. The pension system is not perfect, landless peasants will not be able to provide good support and protection, which for the landless peasants acquire a good life will play a certain negative impact, is not conducive to the stable development of the social economy, while not conducive to the farmer 
Fu-life enhanced sense. Landless peasants of the pension system to conduct a comprehensive and effective and perfect sound for land compensation can be adequate provisions, positive change in the form of compensation for land acquisition compensation, to achieve effective protection of the vital interests of landless peasants actively purpose of. Local governments need to make the correct guidance, conditional participation in pension insurance of landless farmers do ideological work, and some life more difficult for farmers, can be appropriate to reduce the proportion of individual contributions, a corresponding increase government village contribution rate of collective organization [5].

The number of farmers proofing, 2030, the total number of landless peasants will reach 110 million, of which there are more than 50 million farmers will be in a state of unemployment. Many farmers lost their land has been close to old state, and there are more farmers to bear the pressure of family life, if not as a guarantee of a good job, it will cause serious problems for these landless peasants normal life of society stability and economic development will result in some kind of threat. Positive and effective solve the employment problem of landless peasants and landless peasants will be able to effectively alleviate the pressure of life. Our landless farmers need to adopt appropriate safeguards, such as old-age insurance, so that these landless peasants still able to maintain their normal life in old age, but during the course of pension insurance, the landless farmers need to spend more money, and serves the actual results for the current to landless peasants is obvious enough [6]. Thus providing a lot of employment opportunities for landless farmers from landless peasants actually improve living conditions, to constantly improve their living standards, promote good social and economic development has laid an important foundation. Government employment problem of landless peasants actively solving process can be used for good measure the following aspects: First, the loss of employment for landless farmers need the ability to give some compensation. Many farmers lost their land had been older, can not be normal in the corresponding work for this situation, the government needs to give some compensation to ensure the basic livelihood of the landless peasants. Many landless peasants not been able to find suitable employment, mainly because of landless farmers without a high cultural level, there is no more professional skills and less experience while engaged in special work, which would be the normal work of landless peasants affected. Therefore the government needs to landless farmers to carry out the appropriate skills training, the government can send a dedicated technical staff to landless farmers lectures, and landless peasants regular assessment, when the landless farmers to meet the corresponding requirements and standards, can go the workplace [7]. Third, the government and local businesses can cooperate effectively. When the Government placed a large number of farmers, and local businesses can be fully effective cooperation, provide employment opportunities for landless peasants from these companies. After the government and businesses to reach a consensus, the technical requirements from the business point of view, landless farmers appropriate training that could ensure that landless farmers to meet the needs of enterprise development. Fourth, the Government can encourage landless peasants own businesses. For some peasants have their own businesses will, the government can support them to conduct business, such as some private enterprises, self-employed ventures. When the Government wishes to have their own businesses landless peasants support, provides technical support, while also being able to landless farmer small loans to provide some green channel, and for market-related information can be provided effectively. Landless peasants own businesses, not only to solve their employment problems, but also able to create some employment opportunities and provide jobs as part of the landless peasants, which effectively promote local economic development with good results [8].

Governmental organizations at the time of landless peasants to participate in pension insurance, can participate landless peasants pension insurance payment method appropriate modifications, do not necessarily need to pay the full cost of a one-time, you can also take the form of staging, so for ease of landless peasants the economic pressure has a positive effect. At the same time for the landless peasants old-age security, but also need to gradually reduce the contribution rate of landless peasants, gradually increase the contribution rate of government and social organizations. For the treatment of pension insurance for continuous improvement, the current trend of China's aging 
population has gradually clear that for these older farmers, need to be given adequate financial compensation, so that they can spend their remaining years. Also note that, in the landless peasants to provide old-age security, the need for appropriate health care for a sufficient importance [9].

Landless peasants in the process of urbanization can get to the most direct economic benefits, it is the land acquisition compensation, but it is also more prone to lead to land conflicts focus. Thus establishing reasonable land compensation and benefit-sharing mechanism, which is able to effectively compensate for landless peasants. At the time of land acquisition compensation and benefit-sharing mechanism to establish a sound, you first need to land acquisition compensation fee standard for continuous improvement, followed by required from the market point of view, the market as an important orientation and strategic pattern of urban development carried out full and effective combination, determine a reasonable benchmark premium, moreover also we need public functions for effective collective economic security, effective protection of landless peasants have a good source of income [10].

\section{Conclusion}

Urbanization Landless peasants old-age security problems of the present stage are mainly low land compensation fees for the landless farmers can get and the resettlement model currently used is relatively simple, the proportion of insured pension landless peasants still required to pay higher pension insurance contributions is not flexible, and low level of pension benefits. For the urbanization of landless peasants old-age security problem, we need to actively adopt effective ways to improve, specific measures that can be taken mainly are: effectively improve landless peasants pension system, take positive solution to the employment problem of landless peasants, establish a more flexible pension payment method, a gradual increase in pension benefits, as well as establish a rational land requisition compensation and benefit-sharing mechanisms.

\section{Acknowledgements}

Shaanxi Rural Urbanization Landless Peasants insurance system - from the perspective of happiness economic

Project number: 14JK2013.

\section{References}

[1] Li Sheng. Research process of urbanization of landless peasants old-age security problem [J]. managers, 2013 (25): 290

[2] Bai Yudong. Farmers pension issues to explore the town Landless [J]. Agricultural Economy, 2012 (10): 108-109

[3] Zhou Wei, Liu Changxiu. Review of Urbanization in China in the interests of landless peasants Problems [J]. Science and Technology Innovation Herald, 2011 (4): 1-4.

[4] Du Chaoqun. Shanxi Province of Urban Landless Peasants [J]. Shanxi Agricultural University (Social Science Edition), 2014, 13 (1): 32-37.

[5] Zhang Zheng. Research interests of security of landless peasants in the process of urbanization A Case Study of Luoyang, Henan Province [J]. Anhui Agricultural Sciences, 2011,39 (36): 22625-22629.

[6] Zhao Chunjiang, Li Yue. Research urbanization process in the social security of landless peasants [J]. Harbin University of Commerce (Social Science Edition), 2014 (3): 117-119.

[7] Wang Kaiyan. Study of the process of urbanization in the social security of landless peasants [J]. financial sector (Academic Edition), 2016 (2): 285-286.

[8] Li Hongru, Fan Yongxu. The process of urbanization farmer pension policy options [J]. Jiamusi Education Institute, 2013 (11): 437. 
[9] $\mathrm{Wu}$ Hong. studies on the construction of new urbanization interests of landless peasants legal protection [J]. legal Expo, 2015 (30): 18-19.

[10] Yao Hong. Study the process of urbanization in the social security of landless peasants in Henan [J]. Hubei University of Economics (Humanities and Social Sciences), 2014, 11 (5): 67-68. 